\title{
Projected climate change effects on subsurface drainage and the performance of controlled drainage in the Western Lake Erie Basin
}

\author{
L.A. Pease, N.R. Fausey, J.F. Martin, and L.C. Brown
}

\begin{abstract}
The US Midwest is expected to experience higher intensity rainfall events along with an increased chance of drought during the mid- and late 21 st century under projected future climate scenarios. Development of strategies to mitigate the impact of these projected changes on agricultural production and environmental quality is important for ensuring agricultural resiliency to future climate. This study used the DRAINMOD hydrologic model to simulate subsurface drainage discharge at a field site in the headwaters of the Western Lake Erie Basin using future climate patterns projected by 20 general circulation models. Despite projected increases in rainfall, by the late twenty-first century, subsurface discharge was projected to decrease $7 \%$ and $11 \%$ under representative concentration pathway (RCP) 4.5 and RCP 8.5 , respectively. Reductions in subsurface discharge were attributed to increased temperature and evapotranspiration. The performance of controlled drainage was not projected to change on an annual basis throughout the next century. The benefits of controlled drainage systems as an agricultural best management practice were still evident under the projected climate change of the next century. The role of controlled drainage as a means to potentially retain more crop available water in the soil profile could become critically important under future climate conditions.
\end{abstract}

Key words: climate modeling-drainage water management-DRAINMOD-Ohio

Evaluation of current agricultural best management practices, such as controlled drainage, under anticipated climate conditions is necessary to build resilient agricultural systems for the future. Projected changes in the global water balance under climate change will challenge agriculture to meet the demand for increased production to support a growing world population (IPCC 2013; Hatfield et al. 2011). The midwestern United States is an important agricultural region within the United States and is globally producing 10 billion bushels of corn (Zea mays) and 3 billion bushels of soybeans (Glycine max L.) annually (Niyogi and Mishra 2012). Under climate change, the Midwest is projected to experience higher-intensity rainfall events and increased spring rainfall (Pryor et al. 2014). Many agricultural soils in the Midwest are poorly and very poorly drained, leading to
The Western Lake Erie Basin is one of the most extensively drained watersheds of the Midwest (Jaynes and James 2007; Ohio Lake Erie Phosphorus Task Force 2010). While removal of excess water from the soil profile is beneficial for agricultural production, an unintended consequence of subsurface discharge is the delivery of soluble nutrients from agricultural fields to surface waters. Controlled drainage uses an outlet control structure to artificially raise the elevation of the subsurface drainage outlet during periods when drainage is not needed for soil aeration or in-field operations. The primary benefit of controlled drainage for nutrient load reduction is related to its ability to reduce subsurface discharge. Several studies have reported that controlled drainage does not substantially change nitrate $\left(\mathrm{NO}_{3}\right)$ or soluble phosphorus $(\mathrm{P})$ concentrations and found nutrient load reduction to be similar in magnitude to discharge reduction (Williams et al. 2015; Adeuya et al. 2012; Helmers et al. 2012; Jaynes 2012; Wesström and Messing 2007).

Future climate change is not expected to be uniform across regions. Changes in the water balance will depend on local changes in temperature and precipitation (IPCC 2013). For example, Ohio is projected to experience a greater increase in temperature and greater difference in the number of days with heavy precipitation than Iowa by midcentury (Pryor 2014). Singh et al. (2009) and Wang et al. (2015) projected that future climate would increase subsurface drainage discharge in Iowa, but differences in rainfall and temperature between Ohio and Iowa could affect subsurface drainage discharge differently in these two states. To determine how climate change will impact subsurface drainage discharge within the Western Lake Erie Basin, it is necessary to evaluate the water balance with localized climate projections. face drainage discharge and soluble nutrient loads from the agricultural landscape within the Western Lake Erie Basin (Lake Erie Phosphorus Task Force 2010). While subsurface drainage is a critical component of the agricultural water balance in the Midwest, knowledge about the impacts of future climate change on subsurface hydrology and the performance of controlled drainage is limited. Understanding the impact of climate change on the amount and seasonal distribution of subsurface drainage is critical for determining future strategies to preserve agricultural production and environmental quality.
Lindsay A. Pease is formerly a graduate research associate in the Department of Food, AgriculturUniversity, Columbus, Ohio. Norman R. Fausey is a research soil scientist at the Soil Drainage Research Unit, USDA Agricultural Research Service, Columbus, Ohio. Jay F. Martin is a professor in the Department of Food, Agricultural, and Biological Engineering, and Ohio Sea Grant Program, The Ohio State University, Columbus, Ohio. Larry C. Brown is a professor in the Department of Food, Agricultural, and Biological Engineering, The Ohio State University, Columbus, Ohio. al, and Biological Engineering, The Ohio State 
This study simulated subsurface drainage discharge and the performance of controlled drainage in the Western Lake Erie Basin using the DRAINMOD computer model during midcentury (2041 to 2070) and late-century (2071 to 2098) periods using an equal weighting Multimodel Ensemble (MME) approach under two future climate scenarios. The MME approach is well accepted for synthesizing the results from multiple general circulation models (GCMs) and was used in the Fifth Assessment Report of the Intergovernmental Panel on Climate Change (IPCC) to assess changes in the global water balance and mean surface temperatures relative to the historical period (Weigel et al. 2010; Flato et al. 2013; IPCC 2013).

Agricultural resiliency to climate change requires an understanding of how changes will impact current management practices. The objectives of this study were (1) to identify how future changes in rainfall and temperature will alter seasonal and annual subsurface drainage and (2) to evaluate the performance of controlled drainage as an agricultural best management practice under future climate conditions. Change in subsurface hydrology may indicate that change in drainage system design will be beneficial in the future. Change in the performance of controlled drainage systems may indicate that different management strategies will be required to enhance water quality and agricultural productivity.

\section{Materials and Methods}

To carry out this study, the following procedural steps were followed. Precipitation and subsurface drainage discharge were measured during a three-year study period at a field site in the Western Lake Erie Basin. These data, along with drainage system design and soil property information, were used to calibrate and validate the DRAINMOD model so that it could be used to estimate drain discharge under future climate scenarios. The future climate inputs that were used were synthesized using the MME procedure described by Tebaldi and Knutti (2007). These procedural steps are described more fully in the following sections.

Study Area and Observed Data. Observed data used for this study were collected from a privately owned field in Auglaize County, Ohio, from 2013 to 2015. The site is located in the headwaters of the Western Lake Erie Basin (figure 1). Soils at this site belong pri-

\section{Figure 1}

Location of the field site within the Western Lake Erie Basin (hatched area) and the approximate site location (black square). Inset: drainage system layout.

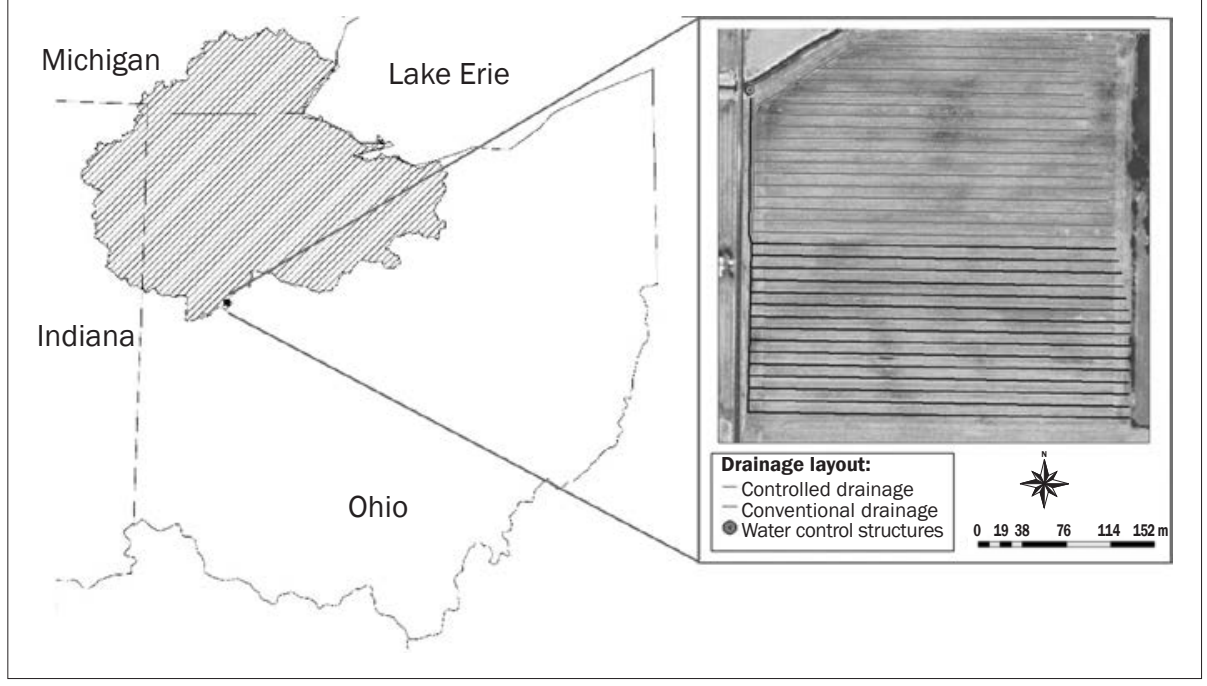

marily to the Minster (fine, mixed, active, mesic Typic Endoaquolls) soil series with small areas of Blount (fine, illitic, mesic Aeric Epiaqualfs). These soils are classified as very poorly drained and have less than $1 \%$ slope on average.

The subsurface drainage system at this site

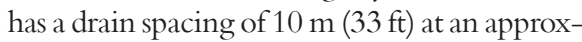
imate depth of $1 \mathrm{~m}(3.3 \mathrm{ft})$ below the soil surface. Two water control structures (WCS) (Agri Drain Corporation, Adair, Iowa) were installed in 2007 at the main drainage outlets for management of drainage system outlet elevation. The north portion of the field (7.16 ha $[17.7 \mathrm{ac}])$ was managed with controlled drainage, and the south portion (7.28 ha [18 ac]) was left unmanaged to represent the conventional or freely drained condition.

Subsurface drainage discharge volume was determined by measuring the height of flow through and over a $7.6 \mathrm{~cm}$ (3 in) wide by $10.2 \mathrm{~cm}$ (4 in) deep v-notch weir cut into the topmost board in the WCS. Both controlled and conventionally drained WCS contained a v-notch weir board at all times. Water level upstream of the board setting was recorded at 15 minute intervals in each WCS using a Solinst Model 3001 Levelogger pressure transducer (Solinst Canada Ltd., Georgetown, Ontario, Canada). Manual readings were taken upstream of the boards to monitor drift in the recorded water levels. Flow height above the bottom of the v-notch weir was converted to flow rate using flow rating curves derived from an unpublished flow rating curve study as described by Gunn et al. (2015). "Conventional drainage" refers to the condition in which only a v-notch board was in place at the bottom of the WCS for discharge calculation purposes while "controlled drainage" refers to the condition in which one or more boards and a v-notch weir board were placed in the WCS to elevate the outlet. The adjustable boards in the WCS for the controlled drainage system were set to raise the drainage outlet when no crop was on the field and during the growing season. The outlet was set to conventional drainage levels prior to planting and harvest to assure field trafficability.

Rainfall was monitored using a TR-525I rainfall tipping bucket (Texas Electronics, Dallas, Texas). Field observations of rainfall were corrected to adjust for underestimation by the tipping bucket mechanism using the methodology described in Shedekar et al. (2016) for the TR-525 tipping bucket model. Missing rain gauge data were estimated on a daily basis using the Inverse Distance Weighting (IDW) method from available rainfall data recorded at locations within a $30 \mathrm{~km}$ (19 mi) radius of the field site (Ashraf et al. 1997). Rainfall observations for use with the IDW method were obtained from observed data at a nearby research site recorded by a Model 100 rainfall tipping bucket (Automata, Nevada City, California), and weather station data included in the National Oceanic and Atmospheric Administration National Climatic Data Center GHCN-Daily Database (Menne et al. 2012). Approximately $50 \%$ of the rainfall record from 2013 to 2015 required estimation using the IDW method. 
Subsurface Drainage Discharge Modeling. Subsurface drainage discharge under future climate scenarios was simulated using DRAINMOD 6.1. DRAINMOD is a fieldscale, process-based hydrologic model used to simulate water balance for high water table and artificially drained soils (Skaggs 1978). DRAINMOD uses climatological records and soil characteristics to simulate water balance at hourly and daily time scales (Skaggs et al. 2012).

DRAINMOD has been used to simulate performance of controlled drainage systems (Ale et al. 2009; Luo et al. 2010; Skaggs et al. 2010) and the effect of future climate scenarios on subsurface drainage systems and bioretention areas (Singh et al. 2009; Dayyani et al. 2012; Hathaway et al. 2014).

DRAINMOD Parameterization. Soil water retention and bulk density to a depth of $60 \mathrm{~cm}$ (24 in) were based on soil cores collected from the field site in 2011 and 2013 according to the standardized procedures and methodology agreed upon by the USDA National Institute of Food and Agriculture (NIFA) funded Climate and Corn-based Cropping Systems Coordinated Agricultural Project as described in Kladivko et al. (2014). These data were uploaded to a centralized database for review and quality control by data managers to ensure data integrity and adherence to standardization (Herzmann et al. 2014). Soil water retention and bulk density between 60 and $203 \mathrm{~cm}$ (24 to $80 \mathrm{in}$ ) in depth were obtained from estimates in the USDA Natural Resources Conservation Service (NRCS) Web Soil Survey. Saturated hydraulic conductivity was estimated from available soils data using the ROSETTA computer model (table 1). The ROSETTA model approximates soil pedotransfer hydrologic parameters using hierarchical neural network functions (Schaap et al. 1998). Other required DRAINMOD input parameters and their sources are listed in table 2 .

Daily precipitation amounts were disaggregated on an hourly basis to fall within a four-hour time window starting at 10:00 AM EST using a routine within the DRAINMOD program. The starting time and duration of this window were based on the statistical probability of rainfall starting within a given hour and lasting for durations of 1 to 24 hours in observed hourly rainfall measurements recorded between 2011 and 2014 at this field site. Daily maximum and minimum temperature observations were obtained from the weather station at the Allen County Airport in Lima, Ohio, located approximately $22 \mathrm{~km}$ $(14 \mathrm{mi})$ from the field location.

Evapotranspiration (ET) was simulated from temperature parameters using the Thornthwaite equation for estimated potential ET using the subroutine for monthly ET in the DRAINMOD model (Thornthwaite 1948). One limitation of this method is that the Thornthwaite method of estimating ET does not account for change in atmospheric carbon dioxide $\left(\mathrm{CO}_{2}\right)$ concentration. By the end of the century, atmospheric $\mathrm{CO}_{2}$ is projected to rise to approximately $650 \mathrm{ppm}$ $\mathrm{CO}_{2}$ equivalent under RCP 4.5 and 1,370 ppm $\mathrm{CO}_{2}$ equivalent under RCP 8.5 (Moss et al. 2008). Although rise in $\mathrm{CO}_{2}$ equivalent is unaccounted for, prior studies have concluded that this will have minimal impact on the agricultural water balance (Field et al. 1995; Wang et al. 2015).

Evaluation of DRAINMOD Model Performance. Nash-Sutcliffe Modeling Efficiency (NSE) was used to evaluate subsurface discharge volume on a daily and monthly basis (Nash and Sutcliffe 1970), and percentage normalized error (PNE) was used to evaluate subsurface drainage discharge on an annual basis as recommended by Skaggs et al. (2012). NSE is a commonly used model calibration parameter for DRAINMOD (Youssef et al. 2006; Ale et al. 2009; Luo et al. 2010; Skaggs et al. 2012; Hathaway et al. 2014). Thresholds of model suitability using NSE and PNE were based on an assessment by Skaggs et al. (2012) of published studies that used in-field monitoring data to calibrate DRAINMOD. This assessment determined that for DRAINMOD, daily calibrations resulting in subsurface discharge with NSE $>0.4$ were "acceptable," NSE > 0.60 were "good," and NSE > 0.75 were "excellent." Monthly calibrations resulting in subsurface discharge with NSE > 0.5 were "acceptable," NSE > 0.70 were "good," and NSE > 0.80 were "excellent." For annual subsurface discharge, PNE < 25\% is "acceptable," PNE < $15 \%$ is "good," and PNE $<5 \%$ is "excellent."

Skaggs et al. (2012) recommends at least one year of data be used for calibration. Approximately three years of data (January 1, 2013, to November 20, 2015) were available for model calibration and validation for this study. Soil properties were generally consistent between the conventional drainage half of the field and the controlled drainage half of the field, so measurements from both drainage systems were used for model evaluation. Subsurface drainage discharge from the conventional drainage treatment from 2013 to 2015 were used in model calibration while subsurface drainage discharge and WCS board settings from the controlled drainage treatment from 2013 to 2015 were used in model validation. Daily, monthly, and annual statistics indicate that the model provided a reasonable fit for both the conventional and controlled drainage systems (table 3 ).

Model Adjustments for Future Climate Runs. For future climate simulations, weir settings for simulating controlled drainage management within DRAINMOD were based on recommended management guidelines for Ohio (Fausey 2016). Weir boards were set to $30 \mathrm{~cm}$ (12 in) below the ground surface for the nongrowing season (October 21 to April 1) and $46 \mathrm{~cm}$ (18 in) below the ground surface during the growing season (June 15 to September 21). Weir depth was set to drain depth to represent a "freely drained" condition during windows for planting and early crop establishment (April 1 to June 15) and harvest (September 21 to October 21).

Projections of Future Rainfall and Temperature. Future climate projections are informed by the amount of radiative forcing projected through the end of the 21st century (Moss et al. 2010). Radiative forcing indicates the difference in the amount of sunlight that is absorbed by the Earth's surface and atmosphere instead of radiated back to space and is influenced by concentrations of greenhouse gasses (GHGs) in the atmosphere. This study examines changes in subsurface drainage discharge patterns under two future radiative forcing scenarios known as representative concentration pathways (RCPs). RCPs were adopted by the Intergovernmental Panel on Climate Change (IPCC) in its Fifth Assessment Report to cover a range of radiative forcing levels resulting from projected changes in socioeconomic factors and GHG emissions through the end of the 21st century (Moss et al. 2010). RCP 4.5 represents a climate scenario in which global population stabilizes at 9 billion, and global emissions reduction policies lead to a peak in GHG emissions by 2050 with a decline to stable levels by 2080. Under this scenario, radiative forcing stabilizes at $4.5 \mathrm{~W} \mathrm{~m}^{-2}\left(1.2 \mathrm{Btu} \mathrm{h}^{-1} \mathrm{ft}^{-2}\right)$ above preindustrial levels in 2100 (Thomson et al. 2011). RCP 8.5 represents a "business 


\section{Table 1}

Soil physical properties used as ROSETTA model inputs.

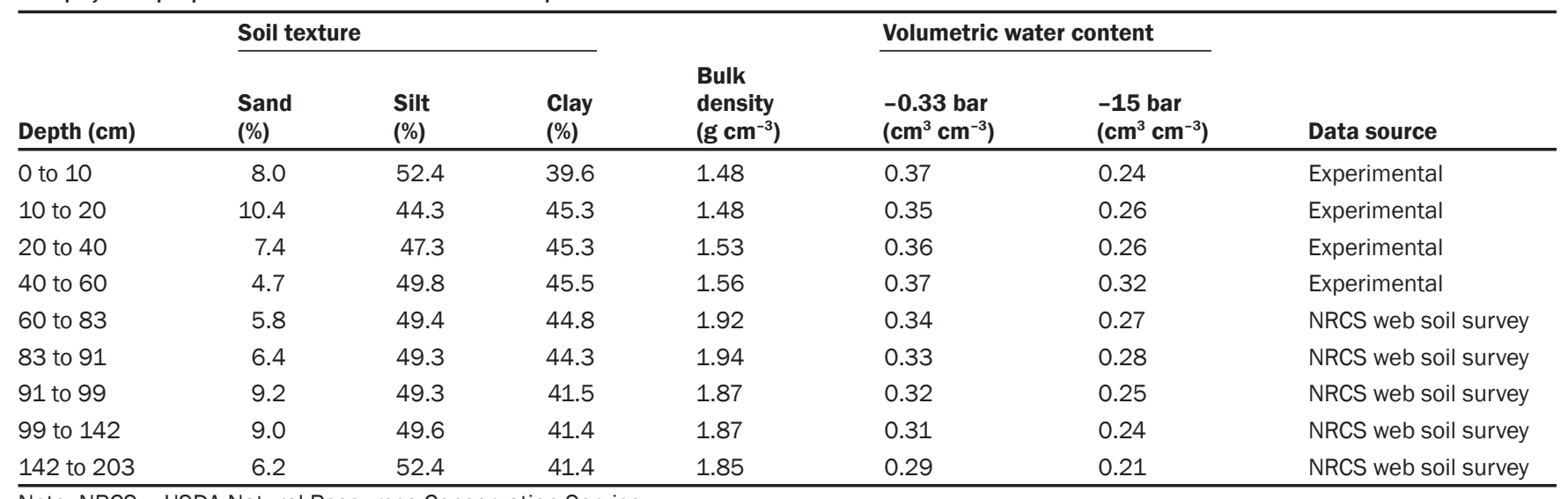

Note: NRCS = USDA Natural Resources Conservation Service.

as usual" climate scenario in which global population increases to 12 billion by 2100 with no significant global climate policies to reduce GHG emissions. This is the highest GHG emissions scenario with radiative forcing increasing to $8.5 \mathrm{~W} \mathrm{~m}^{-2}\left(2.7 \mathrm{Btu} \mathrm{h}^{-1} \mathrm{ft}^{-2}\right)$ above preindustrial levels in 2100 (Riahi et al. 2011).

All of the available GCMs from Phase Five of the Coupled Model Intercomparison Project (CMIP5) that had been downscaled for the contiguous United States were employed (table 4). Downscaled projections were obtained from the "Downscaled CMIP3 and CMIP5 Climate and Hydrology Projections" archive at http://gdo-dcp.ucllnl. org/downscaled_cmip_projections/ (Maurer et al. 2007). Projections were bias-corrected and statistically downscaled to a daily time scale and to $1 / 8^{\circ}$ spatial resolution (about $140 \mathrm{~km}^{2}\left[54 \mathrm{mi}^{2}\right]$ per grid cell) using the Bias-Correction Constructed Analogues (BCCA) method (Bureau of Reclamation 2013). The grid cell used in this study was centered at $40^{\circ} 33^{\prime} 45^{\prime \prime} \mathrm{N}, 84^{\circ} 3^{\prime} 45^{\prime \prime} \mathrm{W}$. Using this method, 19 and 20 GCMs were available for RCP 4.5 and 8.5, respectively. CanESM2, CCSM4, CSIRO-Mk3.6.0 IPSL-CM5A-LR, MIROC5, MPIESM-LR, and MPI-ESM-MR (for RCP 4.5 only) had multiple members representing internal model variability due to different initial time conditions (table 4). Altogether, 83 climate projections were utilized as inputs for DRAINMOD simulations. Prior to analysis, daily precipitation data from the GCMs were disaggregated on an hourly basis in the same way as field-observed data. The results of the DRAINMOD simulations were synthesized using the equal weighting MME approach (Robertson et al. 2004; Tebaldi and Knutti 2007; Weigel et al. 2010; Flato et al. 2013). The equal weighting MME approach is a simple average of the results from multiple GCMs to represent the "best guess" for future projections (Tebaldi and Knutti 2007). In future climate studies, the term MME refers to a collection of simulations from different GCMs (Tebaldi and Knutti 2007; Flato et al. 2013). Use of a MME provides a more robust future projection than the use of a single GCM (Robertson et al. 2004; Weigel et al. 2010). In this study, seven GCMs had multiple members. In these cases, simulation results from all members of the GCM were averaged prior to calculating the MME mean to preserve equal weighting.

MME means over a 30-year period were used to evaluate changes in rainfall, temperature, and subsurface drainage discharge between the historical period (1971 to 2000), midcentury (2041 to 2070), and late-century (2071 to 2098). For rainfall and subsurface discharge, daily totals were summed on both an annual and monthly basis, then averaged over the 30-year period. For minimum and maximum temperature, daily high and low temperatures were averaged on a monthly and annual basis, and then were averaged over the 30-year period.

Statistical Analysis. All statistical analyses were performed in JMP 11.0 (SAS Institute 2013) at $\alpha<0.05$. Comparisons between controlled and conventional drainage at the study site from 2013 to 2015 were conducted on a daily, monthly, and seasonal basis using $t$-tests. Daily subsurface discharge was tested with a $t$-test on days without management to compare baseline differences between the two drainage systems. Analyses of statistical significance between historical, midcentury, and late-century time periods were conducted using ANOVA and the Tukey-Kramer honest significant difference (HSD) test (Tukey 1953; Kramer 1956).

\section{Results and Discussion}

Observed Subsurface Drainage Discharge: 2013 to 2015. Under current climate conditions, controlled drainage reduces subsurface drainage discharge. During the study period, annual observed discharge was reduced between $16 \%$ and $24 \%$ on an annual basis (table 5). When the controlled drainage outlet was set to drain depth, there was no difference in outlet elevation between controlled drainage and conventional drainage. This condition occurred on a total of 453 monitored days during the three-year study period. During unmanaged periods, no statistically significant difference was observed in daily subsurface drainage discharge between controlled and conventional drainage systems. During managed periods (total of 569 monitored days), daily subsurface discharge from the controlled drainage system was significantly lower than from the conventional drainage system. Observed mean monthly discharge from 2013 to 2015 was $3.1 \mathrm{~cm}$ (1.2 in) for controlled drainage and 4.3 $\mathrm{cm}$ (1.7 in) for conventional drainage for a statistically significant mean monthly reduction of $1.3 \mathrm{~cm}$ (0.5 in). Controlled drainage management resulted in significant seasonal reductions in subsurface discharge during winter (January, February, and March) and summer (July, August, and September). No significant differences between controlled and conventional discharge were observed 
Table 2

Input parameters for DRAINMOD.

\begin{tabular}{|c|c|c|c|}
\hline Parameter & Value & Unit & Source \\
\hline \multicolumn{4}{|l|}{ Drainage system design } \\
\hline Depth to drains from soil surface & 114 & $\mathrm{~cm}$ & Drainage system design and calibration \\
\hline Effective radius of drains & 0.51 & $\mathrm{~cm}$ & Drainage system design; Skaggs (1980) \\
\hline Distance to impermeable layer & 203 & $\mathrm{~cm}$ & NRCS web soil survey \\
\hline Drainage coefficient & 1.27 & $\mathrm{~cm}$ & Drainage system design \\
\hline Kirkham's depth for flow to drains & 1 & $\mathrm{~cm}$ & Workman and Fausey (1985) \\
\hline \multicolumn{4}{|l|}{ Lateral seepage } \\
\hline Thickness of transmissive layer & 100 & $\mathrm{~cm}$ & Calibration \\
\hline Hydraulic head of receiving waters & 30 & $\mathrm{~cm}$ & Calibration \\
\hline Distance to receiving waters & 19,000 & $\mathrm{~cm}$ & Distance to stream \\
\hline $10 \mathrm{~cm}$ & 7.23 & $\mathrm{~cm} \mathrm{~h}^{-1}$ & ROSETTA model output \\
\hline $20 \mathrm{~cm}$ & 3.68 & $\mathrm{~cm} \mathrm{~h}^{-1}$ & ROSETTA model output \\
\hline $40 \mathrm{~cm}$ & 4.80 & $\mathrm{~cm} \mathrm{~h}^{-1}$ & ROSETTA model output \\
\hline $60 \mathrm{~cm}$ & 3.89 & $\mathrm{~cm} \mathrm{~h}^{-1}$ & ROSETTA model output \\
\hline $83 \mathrm{~cm}$ & 1.04 & $\mathrm{~cm} \mathrm{~h}^{-1}$ & ROSETTA model output \\
\hline \multicolumn{4}{|l|}{ Soil temperature } \\
\hline Thermal conductivity function coefficients & $a=0.39 ; b=1.33$ & & DRAINMOD default value \\
\hline Average air temperature below which precipitation is snow & -2 & ${ }^{\circ} \mathrm{C}$ & Calibration \\
\hline Average air temperature above which snow starts to melt & 0 & ${ }^{\circ} \mathrm{C}$ & Calibration \\
\hline Snow melt coefficient & 5 & $\mathrm{~mm} \mathrm{dd^{-1 }}$ & Calibration \\
\hline \multicolumn{4}{|l|}{ Root depths (by date) } \\
\hline May 5 & 3 & $\mathrm{~cm}$ & Skaggs (1980) and calibration \\
\hline June 20 & 20 & $\mathrm{~cm}$ & Skaggs (1980) and calibration \\
\hline July 18 & 45 & $\mathrm{~cm}$ & Skaggs (1980) and calibration \\
\hline Aug. 30 & 80 & $\mathrm{~cm}$ & Skaggs (1980) and calibration \\
\hline Sept. 30 & 80 & $\mathrm{~cm}$ & Skaggs (1980) and calibration \\
\hline Oct. 20 & 3 & $\mathrm{~cm}$ & Skaggs (1980) and calibration \\
\hline \multicolumn{4}{|l|}{ Trafficability } \\
\hline Minimum air volume required to work the land & 2 & $\mathrm{~cm}$ & Nolte et al. (1983) \\
\hline Minimum rain to delay work & 0.5 & $\mathrm{~cm}$ & Nolte et al. (1983) \\
\hline Delay after rain to restart work & 1 & d & Nolte et al. (1983) \\
\hline \multicolumn{4}{|l|}{ First work period } \\
\hline Start date & Apr. 10 & & Barker et al. (2005) \\
\hline End date & June 15 & & Barker et al. (2005) \\
\hline \multicolumn{4}{|l|}{ Second work period } \\
\hline Start date & Oct. 1 & & Barker et al. (2005) \\
\hline End date & Dec. 31 & & Barker et al. (2005) \\
\hline
\end{tabular}




\section{Table 3}

Calibration and validation results for parameterization of the DRAINMOD model to the study site in Auglaize County, Ohio, from 2013 to 2015, using criteria of model performance as described in Skaggs et al. (2012).

\begin{tabular}{|c|c|c|c|c|c|c|c|}
\hline \multirow[b]{2}{*}{ Data set } & \multirow{2}{*}{$\begin{array}{l}\text { Drainage } \\
\text { system }\end{array}$} & \multicolumn{2}{|c|}{ Daily NSE* } & \multicolumn{2}{|c|}{ Monthly NSE } & \multicolumn{2}{|c|}{ Annual PNE† } \\
\hline & & Value & Criteria & Value & Criteria & Value & Criteria \\
\hline Calibration: & Conventional & 0.38 & Acceptable & 0.67 & Acceptable & $-10 \%$ & Good \\
\hline Validation: & Controlled & 0.37 & Acceptable & 0.75 & Good & $1.4 \%$ & Excellent \\
\hline
\end{tabular}

during spring (April, May, and June) or autumn (October, November, and December).

These results were consistent with the findings of other controlled drainage studies in Ohio. Williams et al. (2015) found 8\% to $34 \%$ annual reductions in annual subsurface discharge through use of controlled drainage management during an eight-year study period in an Ohio headwater watershed. Within the Western Lake Erie Basin, Gunn et al. (2015) found that controlled drainage reduced daily subsurface drainage discharge by $40 \%$ to $100 \%$ during managed periods.

Projected Changes in Temperature and Precipitation under Future Climate Conditions. All CMIP5 GCMs projected an increase in mean daily temperature throughout the next century (table 6). Under RCP 4.5 mean daily high and low temperatures were projected to stabilize around 2040 while under RCP 8.5 mean daily high and low temperatures were projected to increase through 2098 (table 7). MME mean daily high temperatures for the midcentury period increased $2.6^{\circ} \mathrm{C}\left(4.7^{\circ} \mathrm{F}\right)$ under RCP 4.5 and $3.4^{\circ} \mathrm{C}\left(6.1^{\circ} \mathrm{F}\right)$ under RCP 8.5 above

\section{Table 4}

Coupled Model Intercomparison Project Phase 5 general circulation models and modeling groups included in this study.

\begin{tabular}{|c|c|c|}
\hline Model name & Model center (or group) & Ensemble members \\
\hline ACCESS1.3 & $\begin{array}{l}\text { Commonwealth Scientific and Industrial Research Organization (CSIRO) } \\
\text { and Bureau of Meteorology (BOM), Australia }\end{array}$ & $\mathrm{RCP} * 4.5$ - r1i1p1†, RCP 8.5 - r1i1p1 \\
\hline BCC-CSM1.1 & Beijing Climate Center, China Meteorological Administration & RCP 4.5 - r1i1p1, RCP 8.5 - r1i1p1 \\
\hline CanESM2 & Canadian Centre for Climate Modelling and Analysis & RCP 4.5 - r[1-5]i1p1, RCP 8.5 - r[1-5]i1p1 \\
\hline CCSM4 & National Center for Atmospheric Research & RCP 4.5 - r[1-2]i1p1, RCP 8.5 - r[1-2]i1p1 \\
\hline CESM1(CAM5) & Community Earth System Model Contributors & RCP 4.5 - r1i1p1, RCP 8.5 - r1i1p1 \\
\hline CNRM-CM5 & $\begin{array}{l}\text { Centre National de Recherches Météorolgiques/Centre Européen de } \\
\text { Recherche et Formation Avancée en Calcul Scientifique }\end{array}$ & RCP 4.5 - r1i1p1, RCP 8.5 - r1i1p1 \\
\hline CSIRO-Mk3.6.0 & $\begin{array}{l}\text { Commonwealth Scientific and Industrial Research Organization (CSIRO) } \\
\text { in collaboration with Queensland Climate Change Centre of Excellence }\end{array}$ & RCP 4.5 - r[1-10]i1p1, RCP 8.5 - r[1-10]i1p1 \\
\hline GFDL-CM3 & $\begin{array}{l}\text { National Oceanic and Atmospheric Administration (NOAA) Geophysical Fluid } \\
\text { Dynamics Laboratory }\end{array}$ & RCP 8.5 - r1i1p1 \\
\hline GFDL-ESM2G & NOAA Geophysical Fluid Dynamics Laboratory & RCP 4.5 - r1i1p1, RCP 8.5 - r1i1p1 \\
\hline GFDL-ESM2M & NOAA Geophysical Fluid Dynamics Laboratory & RCP 4.5 - r1i1p1, RCP 8.5 - r1i1p1 \\
\hline INM-CM4 & Institute for Numerical Mathematics & RCP 4.5 - r1i1p1, RCP 8.5 - r1i1p1 \\
\hline IPSL-CM5A-LR & Institute Pierre-Simon Laplace & RCP 4.5 - r[1-4]i1p1, RCP 8.5 - r[1-4]i1p1 \\
\hline IPSL-CM5A-MR & Institute Pierre-Simon Laplace & RCP 4.5 - r1i1p1, RCP 8.5 - r1i1p1 \\
\hline MIROC5 & $\begin{array}{l}\text { Atmosphere and Ocean Research Institute (The University of Tokyo), } \\
\text { National Institute for Environmental Studies, and Japan Agency for } \\
\text { Marine-Earth Science and Technology }\end{array}$ & RCP 4.5 - r[1-3]i1p1, RCP 8.5 - r[1-3]i1p1 \\
\hline MIROC-ESM & $\begin{array}{l}\text { Japan Agency for Marine-Earth Science and Technology, Atmosphere } \\
\text { and Ocean Research Institute (The University of Tokyo), and } \\
\text { National Institute for Environmental Studies }\end{array}$ & RCP 4.5 - r1i1p1, RCP 8.5 - r1i1p1 \\
\hline MIROC-ESM-CHEM & $\begin{array}{l}\text { Japan Agency for Marine-Earth Science and Technology, Atmosphere } \\
\text { and Ocean Research Institute (The University of Tokyo), and } \\
\text { National Institute for Environmental Studies }\end{array}$ & RCP 4.5 - r1i1p1, RCP 8.5 - r1i1p1 \\
\hline MPI-ESM-LR & Max-Planck-Institut für Meteorologie (Max Planck Institute for Meteorology) & RCP 4.5 - r[1-3]i1p1, RCP 8.5 - r[1-3]i1p1 \\
\hline MPI-ESM-MR & Max-Planck-Institut für Meteorologie (Max Planck Institute for Meteorology) & RCP 4.5 - r[1-3]i1p1, RCP 8.5 - r1i1p1 \\
\hline MRI-CGCM3 & Meteorological Research Institute & RCP 4.5 - r1i1p1, RCP 8.5 - r1i1p1 \\
\hline NorESM-M & Norwegian Climate Centre & RCP 4.5 - r1i1p1, RCP 8.5 - r1i1p1 \\
\hline
\end{tabular}

*RCP indicates the representative concentration pathway simulated for each climate model.

$\dagger$ Ensemble members are represented using: $r<\mathrm{N}>i<\mathrm{M}>p<\mathrm{L}>$ format where $r$ is the initial condition (time), $i$ is the initialization method, and $p$ is the perturbed physics ensemble (Taylor et al. 2009). 


\section{Table 5}

Observed subsurface discharge from conventional and controlled drainage systems at the study site in Auglaize County, Ohio, from 2013 to 2015.

\begin{tabular}{llll}
\hline & \multicolumn{3}{l}{ Year } \\
\cline { 2 - 4 } Drainage system & $\mathbf{2 0 1 3}$ & $\mathbf{2 0 1 4}$ & $\mathbf{2 0 1 5}$ \\
\hline Conventional $(\mathrm{cm})$ & 45 & 41 & 66 \\
Controlled $(\mathrm{cm})$ & 34 & 33 & 56 \\
\hline Reduction $(\%)$ & 24 & 20 & 16 \\
\hline
\end{tabular}

the average from the historical period (table 6). MME mean daily high temperatures during the late-century period increased by an average of $3^{\circ} \mathrm{C}\left(5.4^{\circ} \mathrm{F}\right)$ under RCP 4.5 and $5.4^{\circ} \mathrm{C}\left(9.7^{\circ} \mathrm{F}\right.$ ) under RCP 8.5 (table 7). MME mean daily low temperatures exhibited a similar trend to daily high temperatures (table 7). Significant increases in temperature over the historical period were projected during the midcentury period and the late-century period in every season for both RCP 4.5 and RCP 8.5 (table 8).

There was high agreement among CMIP5 GCMs that annual precipitation would increase under both scenarios for the midcentury and late-century periods (table 6). Greater increases in annual precipitation were projected for RCP 4.5 than for RCP 8.5 (table 7). By midcentury, annual precipitation was projected to increase $4.4 \%$ under RCP 4.5 and 3.4\% under RCP 8.5 (table 7). By late-century, annual precipitation was projected to increase 5.3\% under RCP 4.5 and 5\% under RCP 8.5 (table 7). Seasonal precipitation was projected to increase significantly compared to the historical period during winter, spring, and autumn under both RCP 4.5 and 8.5 (table 8). No signif- icant differences from the historical period were observed during summer. Under RCP 8.5 , precipitation was projected to increase significantly from the midcentury period to the late-century period during winter, but not during other seasons.

Projected Changes in Conventional Subsurface Drainage Discharge under Future Climate Conditions. Using CMIP5 GCMs to drive DRAINMOD simulations revealed that conventional subsurface drainage discharge is likely to decrease in the Western Lake Erie Basin throughout the next century (table 6). A greater decline in discharge was projected for RCP 8.5 than for RCP 4.5. For RCP 4.5, projected subsurface discharge decreased $12.3 \%$ by midcentury and $14.5 \%$ by late-century (table 7). For RCP 8.5, projected subsurface discharge decreased $14.3 \%$ by midcentury and $23.7 \%$ by late-century (table 7 ). The annual decrease in subsurface discharge was statistically significant between the historical period and midcentury period for RCP 4.5 (table 9). The decrease in subsurface discharge from midcentury to late-century was statistically significant for RCP 8.5 (table 9).

Seasonal subsurface drainage discharge in conventional drainage systems was greatest in winter and lowest in summer under both historical and future climate conditions (table 9). This trend was consistent with the findings of King et al. (2014) for conventional subsurface discharge in an Ohio headwater watershed. The greatest decline in subsurface drainage discharge under future climate conditions was projected to occur during autumn. Under RCP 4.5 depth of subsurface drainage discharge was projected to significantly decrease by an average of $9 \mathrm{~mm}$ (0.4 in) during winter, $7 \mathrm{~mm}$ (0.3 in) during spring, $9 \mathrm{~mm}$ (0.4 in) during summer, and 22 $\mathrm{mm}$ (0.9 in) during autumn by midcentury (table 9). Under RCP 4.5, seasonal subsurface discharge was not projected to change significantly from the midcentury period to the late-century period (table 9). Under RCP 8.5, subsurface drainage discharge was projected to decrease by an average of 8 , 9 , and $30 \mathrm{~mm}$ (0.3, 0.4, and $1.2 \mathrm{in})$ during spring, summer, and autumn, respectively, by midcentury (table 9). Subsurface drainage discharge during winter was not significantly different between the historical and midcentury periods (table 9). Significant decreases in subsurface drainage discharge between the midcentury and late-century periods were projected during winter, summer, and autumn under RCP 8.5 (table 9).

The decrease in annual subsurface discharge found in this study differs from the findings of Singh et al. (2009) and Dayyani et al. (2012), which found overall increases in annual subsurface drainage discharge in Iowa, United States, and Quebec, Canada, respectively. The difference in response to future climate change could be a result of the existing differences in regional hydrology between Ohio and more northern areas of the Midwest and Canada. Under current climate conditions, Ohio soils do not freeze for significant lengths of time during winter. In areas without frozen winter soils, subsurface drainage discharge tends to be greatest from the late fall to the early spring (Randall and Goss 2001). In more northern areas of the Midwest like Iowa, Minnesota,

\section{Table 6}

Number of individual general circulation models projecting an increase or decrease in annual precipitation and temperature, and via DRAINMOD simulation, projecting an increase or decrease in annual subsurface drainage discharge relative to the historical period (1971 to 2000 ) for an agricultural field representative of the Western Lake Erie Basin for two representative concentration pathways (RCPs).

\begin{tabular}{|c|c|c|c|c|c|c|c|}
\hline \multirow[b]{2}{*}{ Variable } & \multirow[b]{2}{*}{ RCP } & \multicolumn{3}{|c|}{ Midcentury (2041 to 2070) } & \multicolumn{3}{|c|}{ Late-century (2071 to 2098) } \\
\hline & & Increase & No change* & Decrease & Increase & No change* & Decrease \\
\hline \multirow[t]{2}{*}{ Daily maximum temperature $\left({ }^{\circ} \mathrm{C}\right)$} & 4.5 & 19 & 0 & 0 & 19 & 0 & 0 \\
\hline & 8.5 & 20 & 0 & 0 & 20 & 0 & 0 \\
\hline \multirow[t]{2}{*}{ Daily minimum temperature $\left({ }^{\circ} \mathrm{C}\right)$} & 4.5 & 19 & 0 & 0 & 19 & 0 & 0 \\
\hline & 8.5 & 20 & 0 & 0 & 20 & 0 & 0 \\
\hline \multirow[t]{2}{*}{ Precipitation (\%) } & 4.5 & 16 & 2 & 1 & 15 & 1 & 3 \\
\hline & 8.5 & 15 & 1 & 4 & 15 & 1 & 4 \\
\hline \multirow[t]{2}{*}{ Conventional subsurface discharge (\%) } & 4.5 & 2 & 1 & 16 & 2 & 0 & 17 \\
\hline & 8.5 & 0 & 0 & 20 & 2 & 0 & 18 \\
\hline
\end{tabular}

*Difference of less than $1 \%$ between the historical period and midcentury or late-century periods. 
Table 7

Multimodel ensemble (MME) mean change in annual temperature and precipitation from general circulation model climate projections, and MME mean change in subsurface drainage discharge as simulated by DRAINMOD relative to the historical period (1971 to 2000) for an agricultural field representative of the Western Lake Erie Basin for two representative concentration pathways (RCPs).

\begin{tabular}{|c|c|c|c|c|}
\hline \multirow[b]{2}{*}{ Variable } & \multicolumn{2}{|c|}{$\begin{array}{l}\text { Midcentury } \\
\text { (2041 to 2070) }\end{array}$} & \multicolumn{2}{|c|}{$\begin{array}{l}\text { Late-century } \\
\text { (2071 to 2098) }\end{array}$} \\
\hline & RCP 4.5 & RCP 8.5 & RCP 4.5 & RCP 8.5 \\
\hline Daily high temperature $\left({ }^{\circ} \mathrm{C}\right)$ & +2.6 & +3.4 & +3.0 & +5.4 \\
\hline Daily low temperature $\left({ }^{\circ} \mathrm{C}\right)$ & +2.7 & +3.5 & +3.2 & +5.4 \\
\hline Precipitation (\%) & +4.4 & +3.4 & +5.3 & +5.0 \\
\hline Conventional subsurface discharge (\%) & -12.3 & -14.3 & -14.5 & -23.7 \\
\hline
\end{tabular}

and Quebec, frozen soils prevent subsurface drainage discharge from occurring during winter months (Randall and Goss 2001; Helmers et al. 2005; Eastman et al. 2010).

Increases in temperature due to climate change are likely to have a greater impact on the seasonal distribution of subsurface drainage areas with frozen winter soils than areas without frozen soils. Both Dayyani et al. (2012) and Singh et al. (2009) project the greatest increases in subsurface drainage discharge during winter and attribute this change to increasing winter temperatures under future climate conditions. Increased winter temperatures would result in less snow accumulation, shorter periods of frozen soil, and increased infiltration of water into the soil profile during winter months leading to increased subsurface drainage discharge (Dayyani et al. 2012; Singh et al. 2009). In Ohio, the increase in winter temperature due to future climate change will not increase infiltration of water into the soil profile. As a result, increases in subsurface drainage discharge in winter and the potential for a subsequent increase in soluble nutrient losses would not be as likely to occur in Ohio as in higher-latitude areas of the Midwest and Canada.

The difference in projected subsurface drainage discharge could also be a result of differences in future climate projections between Ohio, Iowa, and Quebec. Greater increases in average annual temperature coupled with lower average increases in annual precipitation were projected in this study compared to Singh et al. (2009) and Dayyani et al. (2012). Higher temperatures are projected to drive higher rates of ET from increased crop transpiration and soil evaporation (Hatfield et al. 2011). This effect, combined with lower increases in annual precipitation in Ohio compared to Iowa and Quebec, suggests that there may be lower soil moisture in the soil profile under future climate conditions reducing annual subsurface drainage discharge.

Performance of Controlled Drainage under Future Climate Conditions. The annual per- formance of controlled drainage systems was not projected to change as a result of changes in climate throughout the 21st century (table 10). Average annual percentage reductions in discharge did not change significantly over time and ranged between $4.3 \%$ and $6 \%$ for the three time periods examined in this study. This result demonstrates that the environmental benefits of controlled drainage (discharge and soluble nutrient reduction) will remain evident under future climate conditions.

Significant differences in the seasonal performance of controlled drainage systems were observed in summer and autumn. In summer, seasonal reductions in discharge through controlled drainage management were projected to increase significantly from $23.5 \%$ during the historical period to $39.6 \%$ during the midcentury period under RCP 4.5 and from $43.4 \%$ during the midcentury period to $81.8 \%$ during the late-century period under RCP 8.5.

The improved efficiency of controlled drainage during summer months reflects that use of controlled drainage during the growing season could become a critical component of water management under future climate conditions. With increased temperature driving increased ET, the potential for soil water deficits is increased (Hatfield et al. 2011). Reducing water loss through subsurface drains with controlled drainage management could help meet the crop water requirements in spite of increased ET. In addition, farmers are likely to invest in subsurface drainage systems in response to increased rainfall (Loy et al. 2013). In many

\section{Table 8}

Multimodel ensemble mean change in seasonal temperature and precipitation from the historical period (1971 to 2000$)$ to the midcentury (2041 to 2070) and late-century periods (2071 to 2098) for an agricultural field representative of the Western Lake Erie Basin for two representative concentration pathways (RCPs).

\begin{tabular}{|c|c|c|c|c|c|c|c|}
\hline \multirow[b]{2}{*}{ Season } & \multirow[b]{2}{*}{ RCP } & \multicolumn{2}{|c|}{ Low temperature $\left({ }^{\circ} \mathrm{C}\right)$} & \multicolumn{2}{|c|}{ High temperature $\left({ }^{\circ} \mathrm{C}\right)$} & \multicolumn{2}{|c|}{ Precipitation (mm) } \\
\hline & & Midcentury & Late-century & Midcentury & Late-century & Midcentury & Late-century \\
\hline Winter & 4.5 & +2.8 & +3.4 & +2.5 & +2.9 & +17 & +20 \\
\hline \multirow[t]{2}{*}{ Spring } & 4.5 & +2.5 & +3.1 & +2.4 & +2.9 & +14 & +15 \\
\hline & 8.5 & +3.3 & +5.2 & +3.2 & +5.1 & +16 & +21 \\
\hline Summer & 4.5 & +2.8 & +3.3 & +2.8 & +3.2 & -1 & +3 \\
\hline \multirow[t]{2}{*}{ Autumn } & 4.5 & +2.6 & +3.1 & +2.5 & +2.9 & +11 & +12 \\
\hline & 8.5 & +3.3 & +5.2 & +3.4 & +5.3 & +12 & +15 \\
\hline
\end{tabular}

Notes: Winter = January, February, and March. Spring = April, May, and June. Summer = July, August, and September. Autumn = October, November, and December. 
Table 9

Multimodel ensemble mean seasonal and annual conventional subsurface discharge as projected by DRAINMOD simulation for an agricultural field representative of the Western Lake Erie Basin for two representative concentration pathways (RCPs).

\begin{tabular}{lllll}
\hline \multirow{2}{*}{ Season } & & \multicolumn{3}{l}{ Conventional subsurface drainage discharge (mm) } \\
\cline { 3 - 5 } & $\mathbf{R C P}$ & $\begin{array}{l}\text { Historical } \\
\text { (1971 to 2000) }\end{array}$ & $\begin{array}{l}\text { Midcentury } \\
\text { (2041 to 2070) }\end{array}$ & $\begin{array}{l}\text { Late-century } \\
\text { (2071 to 2098) }\end{array}$ \\
\hline Winter & 4.5 & $158 \mathrm{a} *$ & $149 \mathrm{~b}$ & $148 \mathrm{~b}$ \\
& 8.5 & $158 \mathrm{a}$ & $152 \mathrm{a}$ & $139 \mathrm{~b}$ \\
Spring & 4.5 & $125 \mathrm{a}$ & $118 \mathrm{~b}$ & $116 \mathrm{~b}$ \\
& 8.5 & $125 \mathrm{a}$ & $117 \mathrm{~b}$ & $112 \mathrm{~b}$ \\
Summer & 4.5 & $21 \mathrm{a}$ & $12 \mathrm{~b}$ & $11 \mathrm{~b}$ \\
& 8.5 & $19 \mathrm{a}$ & $10 \mathrm{~b}$ & $6 \mathrm{c}$ \\
Autumn & 4.5 & $70 \mathrm{a}$ & $48 \mathrm{~b}$ & $43 \mathrm{~b}$ \\
& 8.5 & $69 \mathrm{a}$ & $39 \mathrm{~b}$ & $26 \mathrm{c}$ \\
\hline Annual & 4.5 & $373 \mathrm{a}$ & $327 \mathrm{~b}$ & $319 \mathrm{~b}$ \\
& 8.5 & $371 \mathrm{a}$ & $318 \mathrm{~b}$ & $283 \mathrm{c}$ \\
\hline
\end{tabular}

Notes: Winter = January, February, and March. Spring = April, May, and June. Summer = July, August, and September. Autumn = October, November, and December.

*Values in the same row indicated by a different lowercase letter are significantly different at $\alpha=0.05$.

\section{Table 10}

Mean seasonal and annual reductions in subsurface drainage discharge through controlled drainage management as simulated by DRAINMOD for an agricultural field representative of the Western Lake Erie Basin for two representative concentration pathways (RCPs).

\begin{tabular}{lcccc}
\hline & \multicolumn{4}{c}{$\begin{array}{l}\text { Reduction in subsurface discharge with controlled } \\
\text { drainage management }\end{array}$} \\
\cline { 3 - 5 } Seasm) & $\begin{array}{l}\text { Historical } \\
\text { (1971 to 2000) }\end{array}$ & $\begin{array}{l}\text { Midcentury } \\
\text { (2041 to 2070) }\end{array}$ & $\begin{array}{l}\text { Late-century } \\
\text { (2071 to 2098) }\end{array}$ \\
\hline Winter & RCP & 26.80 & 25.10 & 27.80 \\
& 4.5 & 26.80 & 24.30 & 26.60 \\
Spring & 8.5 & -19.80 & -19.30 & -17.50 \\
& 4.5 & -19.90 & -18.10 & -18.30 \\
Summer & 8.5 & 4.50 & 4.39 & 4.00 \\
& 4.5 & 4.41 & 2.94 & 3.73 \\
Autumn & 8.5 & 9.44 & 5.84 & 5.04 \\
& 4.5 & 9.29 & 2.64 & 4.46 \\
\hline Annual & 8.5 & 20.90 & 16.00 & 19.30 \\
& 4.5 & 20.30 & 17.00 & 12.50 \\
\hline
\end{tabular}

Notes: Winter = January, February, and March. Spring = April, May, and June. Summer = July, August, and September. Autumn = October, November, and December.

cases this means increasing subsurface drainage density in their fields to maintain spring planting efficiency. The increased potential for water loss due to increased drainage intensity will increase the value of reducing subsurface discharge during the growing season under future climate conditions. Reductions in subsurface drainage discharge through use of controlled drainage represent a potential increase in the available water in the soil profile for crop growth and a poten- tial for increased production benefits through the use of controlled drainage.

Under RCP 8.5, controlled drainage was projected to be less effective at reducing subsurface drainage discharge in autumn during the late-century period compared to the historical period (table 10). Controlled drainage was projected to reduce winter discharge by $17 \%$ to $19 \%$ on average throughout the next century, but was projected to increase spring discharge by $16 \%$ to $18 \%$ on average (table 10 ).
The projected increase in spring subsurface discharge from controlled drainage systems reveals a discrepancy between the parameterized model and the observed data. The model projects that when the WCS is opened nearly all of the water held back through the winter period is released over a two to three day period in April. The release of water from the soil profile was more dramatic in the model simulation than in observed data at the study site. This discrepancy is also reflected through annual percentage reductions in subsurface discharge. The parameterized model predicted average annual reductions between $4 \%$ and $6 \%$, while observed discharge reductions were between $16 \%$ and $24 \%$ annually during the study period. The difference between observed and simulated response to controlled drainage may result from the assumption that vertical seepage was negligible during model parameterization. This assumption was supported by model calibration and by a regional study on vertical seepage in western Ohio, which found saturated hydraulic conductivity through glacial till to be $1.11 \pm 0.556 \times$ $10^{-6} \mathrm{~cm} \mathrm{~s}^{-1}\left(0.002 \pm 0.001\right.$ in $^{h^{-1}}$ ) (Fausey et al. 2000). Although the model provides a reasonable fit to the observed data, the discrepancy reveals that vertical seepage processes may not be adequately represented within the model. A prior DRAINMOD study by Skaggs et al. (2010) concluded that field experiments on controlled drainage were necessary to adequately represent the role of seepage in discharge reduction. While the DRAINMOD model may underestimate the role of seepage in discharge reduction, this limitation does not affect the conclusion of this study that the performance of controlled drainage will not change under future climate.

Although the increase in discharge due to lowering the board settings was overpredicted by the model, this result demonstrates a potential unintended outcome of controlled drainage management. This suggests that alternative strategies for spring management, such as draining the profile slowly instead of draining the entire soil profile at once, could be beneficial in reducing spring discharge and potential release of soluble nutrients from the soil profile. A slower lowering of the drainage outlet could encourage increased losses of water from the soil profile via other pathways (ET or seepage) rather than via the drainage outlet. 


\section{Summary and Conclusions}

This study simulated the performance of subsurface drainage systems under future climate scenarios using the DRAINMOD hydrologic model. Climate change is expected to increase annual rainfall and temperatures in the Western Lake Erie Basin. Despite increases in projected rainfall, by midcentury subsurface drainage discharge was projected to decrease by $12.3 \%$ and $14.3 \%$ under RCP 4.5 and RCP 8.5, respectively. By the late 21 st century, subsurface discharge is projected to decrease $14.5 \%$ under RCP 4.5 and $23.7 \%$ under RCP 8.5 . By the late 21 st century, subsurface drainage discharge was projected to significantly decline compared to the historical period in all seasons with the greatest discharge depth reduction occurring during the autumn.

This study demonstrates that the benefits of controlled drainage under current climate conditions will still be evident under projected future climate. The performance of controlled drainage on an annual basis was not projected to change under future conditions, so controlled drainage will remain an important practice for reducing subsurface drainage discharge and potential soluble nutrient losses under future climate conditions. By the late-century period, controlled drainage was projected to increase in efficiency during summer from a $23.5 \%$ to $24.6 \%$ reduction in subsurface drainage discharge under historical climate conditions to a $42.7 \%$ reduction for RCP 4.5 and an $81.8 \%$ reduction for RCP 8.5 under late-century climate conditions.

With warmer temperatures driving higher rates of ET, increasing soil water storage for potential use by the crop will become increasingly valuable during the growing season. Increases in discharge observed during the spring when the drainage outlet is lowered could indicate the need to more closely examine procedures for lowering the controlled drainage outlet prior to spring planting operations.

\section{Acknowledgements}

This research is part of a regional collaborative project supported by the USDA National Institute of Food and Agriculture (NIFA), Award No. 2011-68002-30190, Cropping Systems Coordinated Agricultural Project: Climate Change, Mitigation, and Adaptation in Corn-based Cropping Systems. The 11 institutions comprising the project team include the following Land Grant Universities and USDA Agricultural Research Service (ARS): Iowa State University, Lincoln University, South Dakota State University, University of Illinois, University of Minnesota,
University of Missouri, University of Wisconsin, and USDA ARS Columbus, Ohio.

This project was funded, in part, by a USDA Natural Resources Conservation Service (NRCS) Conservation Innovation Grant through the Agricultural Drainage Management Coalition (admcoalition.com), an Ohio USDA NRCS State Conservation Innovation Grant through the Maumee Valley RC\&D, an NSF Coupled Human and Natural Systems grant (GRT00022685), Ohio Sea Grant, the Overholt Drainage Education and Research Program, the Department of Food, Agricultural \& Biological Engineering, Ohio Agricultural Research and Development Center, Ohio State University Extension, the Ohio State University, and collaboration with the USDA ARS Soil Drainage Research Unit. We also thank the cooperating farmers for providing their farm as a research and demonstration site and sharing their farm management information.

We acknowledge the World Climate Research Programme's Working Group on Coupled Modelling, which is responsible for the Coupled Model Intercomparison Project (CMIP), and we thank the climate modeling groups (table 4) for producing and making available their model output. The US Department of Energy's Program for Climate Model Diagnosis and Intercomparison provided coordinating support for CMIP and led development of software infrastructure in partnership with the Global Organization for Earth System Science Portals.

\section{References}

Adeuya, R., N. Utt, J.R. Frankenberger, L.C. Bowling, E.J Kladivko, S.M. Brouder, and B. Carter. 2012. Impacts of drainage water management on subsurface drain flow, nitrate concentration, and nitrate loads in Indiana Journal of Soil and Water Conservation 67(6):474-84, doi:10.2489/jswc.67.6.474.

Ale, S., L.C. Bowling, S.M. Brouder, J.R. Frankenberger, and M.A. Youssef. 2009. Simulated effect of drainage water management operational strategy on hydrology and crop yield for Drummer soil in the midwestern United States. Agricultural Water Management 96(4):653-665.

Ashraf, M., J.C. Loftis, and K.G. Hubbard. 1997. Application of geostatistics to evaluate partial weather station networks. Agricultural and Forest Meteorology 84(3-4):255-271.

Barker, D., J. Beuerlein, A. Dorrance, D. Eckert, B. Eisley, R. Hammond, E. Lentz, P. Lipps, M. Loux, R. Mullen, M. Sulc, P. Thomison, and M. Watson. 2005. Ohio Agronomy Guide, 14th ed. Columbus, OH: Ohio State University Extension.

Bureau of Reclamation. 2013. Downscaled CMIP3 and CMIP5 Climate and Hydrology Projections: Release of Downscaled CMIP5 Climate Projections, Comparison with Preceding Information, and Summary of User Needs. Denver, CO: Bureau of Reclamation. http:// gdo-dcp.ucllnl.org/downscaled_cmip_projections/ techmemo/downscaled_climate.pdf.
Dayyani, S., S.O. Prasher,A. Madani, and C.A. Madramootoo. 2012. Impact of climate change on the hydrology and nitrogen pollution in a tile-drained agricultural watershed in eastern Canada. Transactions of the American Society of Agricultural and Biological Engineers (ASABE) 55(2):389-401.

Eastman, M., A. Gollamudi, N. Stampfli, C.A. Madramootoo, and A. Sarangi. 2010. Comparative evaluation of phosphorus losses from subsurface and naturally drained agricultural fields in the Pike River watershed of Quebec Canada. Agricultural Water Management 97(5):596-604.

Fausey, N.R. 2016. Drainage water management: Operation recommendations. Presented at the North Central Extension and Research Activity-217/Agricultural Drainage Management Systems Task Force Annual Meeting, West Lafayette, IN, March 29-30, 2016.

Fausey, N.R., L.C. Brown, H.W. Belcher, and R.S. Kanwar 1995. Drainage water quality in Great Lakes and Cornbelt states. Journal of Irrigation and Drainage Engineering 121(4):283-288.

Fausey, N.R., G.F. Hall, J.M. Bigham, B.J. Allred, and A.D. Christy. Properties of the fractured glacial till at the Madison, Ohio, field workshop pit site. Ohio Journal of Science 1000(3-4):107-112.

Field, C.B., R.B. Jackson, and H.A. Mooney. Stomatal responses to increased $\mathrm{CO}_{2}$ : Implications from the plant to the global scale. Plant, Cell and Environment 18 (10):1214-1225.

Flato, G., J. Marotzke, B. Abiodun, P. Braconnot, S.C. Chou, W. Collins, P. Cox, et al. 2013. Evaluation of climate models. In Climate Change 2013: The Physical Science Basis. Contribution of Working Group I to the Fifth Assessment Report of the Intergovernmental Panel on Climate Change, eds.T.F. Stocker, D. Qin, G.K. Plattner, M.Tignor, S.K. Allen, J. Boschung, A. Nauels, Y. Xia,V. Bex, and P.M. Midgley, 741-866. Cambridge, UK and New York, NY: Cambridge University Press.

Gunn, K.M., N.R. Fausey, Y. Shang,V.S. Shedekar, E. Ghane, M.D. Wahl, and L.C. Brown. 2015. Subsurface drainage volume reduction with drainage water management: Case studies in Ohio, USA. Agricultural Water Management 149(6):131-142.

Hatfield, J.L., K.J. Boote, B.A. Kimball, L.H. Ziska, R.C. Izaurralde, D. Ort, A.M. Thomson, and D. Wolfe. 2011. Climate impacts on agriculture: Implications for crop production. Agronomy Journal 103(2):351-370.

Hathaway, J.M., R.A. Brown, J.S. Fu, and W.F. Hunt. 2014. Bioretention function under climate change scenarios in North Carolina, USA. Journal of Hydrology 519:503-511.

Helmers, M.J., R. Christianson, G. Brenneman, D. Lockett, and C. Pederson. 2012. Water table, drainage, and yield response to drainage water management in southeast Iowa. Journal of Soil and Water Conservation 67(6): 495-501, doi:10.2489/jswc.67.6.495.

Helmers, M.J., P.A. Lawlor, J.L. Baker, S.W. Melvin, and D.W. Lemke. 2005. Temporal subsurface flow patterns from fifteen years in North-Central Iowa. Paper presented at 
the American Society of Agricultural Engineers Annual International Meeting, Tampa, FL, July 17-20, 2005.

Herzmann, D.E., L.J. Abendroth, and L.D. Bunderson. 2014. Data management approach to multidisciplinary agricultural research and syntheses. Journal of Soil and Water Conservation 69(6):180-85, doi:10.2489/ jswc.69.6.180A.

IPCC (Intergovernmental Panel on Climate Change). 2013. Summary for policymakers. In Climate Change 2013:The Physical Science Basis. Contribution of Working Group I to the Fifth Assessment Report of the Intergovernmental Panel on Climate Change, eds. T.F. Stocker, D. Qin, G.K. Plattner, M. Tignor, S.K. Allen, J. Boschung, A. Nauels, Y. Xia,V. Bex, and P.M. Midgley, 1-29. Cambridge, UK, and New York, NY: Cambridge University Press.

Jaynes, D.B. 2012. Changes in yield and nitrate losses from using drainage water management in Central Iowa, United States. Journal of Soil and Water Conservation 67(6):485-494, doi:10.2489/jswc.67.6.485.

Jaynes, D.B., and D.E. James. 2007. The extent of farm drainage in the United States. Paper presented at the Soil and Water Conservation Society Annual Conference, Tampa, FL, July 21-25, 2007.

King, K.W., N.R. Fausey, and M.R. Williams. 2014. Effect of subsurface drainage on streamflow in an agricultural headwater watershed. Journal of Hydrology 519:438-445.

Kladivko, M.J. Helmers, L.J. Abendroth, D. Herzmann, R. Lal, M.J. Castellano, D.S. Mueller, J.E. Sawyer, R.P. Anex, R.W. Arritt, B. Basso, J.V. Bonta, L.C. Bowling, R.M. Cruse, N.R. Fausey, J.R. Frankenberger, P.W. Gassman, A.J. Gassmann, C.L. Kling, A. Kravchenko, J.G. Lauer, F.E. Miguez, E.D. Nafziger, N. Nkongolo, M. O'Neal, L.B. Owens, P.R. Owens, P. Scharf, M.J. Shipitalo, J.S. Strock, and M.B. Villamil. 2014. Standardized research protocols enable transdisciplinary research of climate variation impacts in corn production systems. Journal of Soil and Water Conservation 69(6):532-542, doi:10.2489/jswc.69.6.532.

Kramer, C.Y. 1956. Extension of multiple range tests to group means with unequal numbers of replications. Biometrics 12(3):307-310.

Loy, A., J. Hobbs, J. Arbuckle Jr., L.W. Morton, L. Prokopy, T. Haigh, T. Knoot, C. Knutson, A.S. Mase, J. McGuire, J. Tyndall, and M. Widhalm. 2013. Farmer Perspectives on Agriculture and WeatherVariability in the Corn Belt: A Statistical Atlas, 1-108. Ames, IA: Cropping Systems Coordinated Agricultural Project (CAP): Climate Change, Mitigation, and Adaptation in Corn-Based Cropping Systems.

Luo, W., G.R. Sands, M.A. Youssef, J.S. Strock, I. Song, and D. Canelon. 2010. Modeling the impact of alternative drainage practices in the northern Corn-Belt with DRAINMOD-NII. Agricultural Water Management 97(3):389-398.

Maurer, E.P., L. Brekke, T. Pruitt, and P.B. Duffy. 2007. Fineresolution climate projections enhance regional climate change impact studies. Eos, Transactions American Geophysical Union 88(47):504.

Menne, M.J., I. Durre, R.S. Vose, B.E. Gleason, and T.G. Houston. 2012. An overview of the global historical climatology network-daily database. Journal of Atmospheric and Oceanic Technology 29(7):897-910.

Moss, R., M. Babiker, S. Brinkman, E. Calvo, T. Carter, J. Edmonds, I. Elgizouli, et al. 2008. Towards New Scenarios for Analysis of Emissions, Climate Change, Impacts, and Response Strategies. Geneva: Intergovernmental Panel on Climate Change.

Nash, J.E., and J.V. Sutcliffe. 1970. River flow forecasting through conceptual models part I - A discussion of principles. Journal of Hydrology 10:282-290.

Niyogi, D., and V. Mishra. 2012. Climate-agriculture vulnerability assessment for the midwestern United States. In Climate Change in the Midwest: Impacts, Risks, Vulnerability, and Adaptation, ed. S.C. Pryor, 69-81. Bloomington, IN: Indiana University Press.

Nolte, B.H., N.R. Fausey, and R.W. Skaggs. 1983. Time available for field work on two Ohio soils. Transactions of the American Society of Agricultural Engineers (ASAE) 26(2):445-451.

Ohio Lake Erie Phosphorus Task Force. 2010. Ohio Lake Erie Phosphorus Task Force Final Report. Columbus, $\mathrm{OH}$ : Ohio Environmental Protection Agency, Division of Surface Water. http://www.epa.state.oh.us/ portals/35/lakeerie/ptaskforce/Task_Force_Final_ Report_April_2010.pdf.

Pryor, S.C., D. Scavia, C. Downer, M. Gaden, L. Iverson, R. Nordstrom, J. Patz, and G.P. Roberson. 2014. Chapter 18: Midwest. In Climate Change Impacts in the United States: The Third National Climate Assessment, eds. J.M. Melillo, T.C. Richmond, and G.W. Yohe, 419-440. Washington, DC: US Global Change Research Program.

Randall, G.W., and M.J. Goss. 2001. Nitrate losses to surface water through subsurface, tile drainage. In Nitrogen in the Environment: Sources, Problems and Management, eds. R.F. Follett and J.L. Hatfield, 95-122. Amsterdam: Elsevier B.V.

Riahi, K., R. Shilpa,V. Krey, C. Cho,V. Chirkov, and G. Fischer. 2011. RCP 8.5 - A scenario of comparatively high greenhouse gas emissions. Climatic Change 109:33-57.

Robertson, A.W., U. Lall, S.E. Zebiak, and L. Goddard. 2004. Improved combination of multiple atmospheric GCM ensembles for seasonal prediction. Monthly Weather Review 132(12):2732-2744.

SAS Institute. 2013. JMP Pro (Version 11.0.0). Cary, NC: SAS Institute Inc.

Schaap, M.G., FJ. Leij, and M.T. van Genuchten. 1998. Neural network analysis for hierarchical prediction of soil hydraulic properties. Soil Science Society of America Journal 62(4):847-855.

Shedekar, V.S., K.W. King, N.R. Fausey, A.B.O. Soboyejo, R.D. Harmel, and L.C. Brown. 2016. Assessment of measurement errors and dynamic calibration methods for three different tipping bucket rain gauges. Atmospheric Research 178-179:445-458.

Singh, R., M.J. Helmers, A.L. Kaleita, and E.S. Takle. 2009. Potential impact of climate change on subsurface drainage in Iowa's subsurface drained landscapes. Journal of Irrigation and Drainage Engineering 135(4):459-466.

Skaggs, R.W. 1978. A Water Management Model for Shallow Water Table Soils. Raleigh, NC: University of North Carolina, Water Resources Research Institute.

Skaggs, R.W. 1980. DRAINMOD: Reference Report. Fort Worth, TX: USDA Soil Conservation Service (SCS). http://www.bae.ncsu.edu/soil_water/drainmod/ manuals.html.

Skaggs, R.W., M.A. Youssef, and G.M. Chescheir. 2012. Drainmod: Model use, calibration, and validation. Transactions of the American Society of Agricultural and Biological Engineers 55(4):1509-1522.

Skaggs, R.W., M.A. Youssef, J.W. Gilliam, and R.O. Evans. 2010. Effect of controlled drainage on water and nitrogen balances in drained lands. Transactions of the American Society of Agricultural and Biological Engineers 53(6):1843-1850.

Tebaldi, C., and R. Knutti. 2007. The use of the multimodel ensemble in probabilistic climate projections. Philosophical Transactions: Mathematical, Physical, and Engineering Sciences 365(1857):2053-2075.

Thomson, A.M., K.V. Calvin, S.J. Smith, G.P. Kyle, A. Volke, P. Patel, S. Delgado-Arias, B. Ben-Lamberty, M.A. Wise, L.E. Clarke, and J.A. Edmonds. 2011. RCP 4.5: A pathway for stabilization of radiative forcing by 2100. Climatic Change 109:77-94.

Thornthwaite, C.W. 1948. An approach toward a rational classification of climate. Geographical Review 38(1):55-94.

Tukey, J.W. 1953. The problem of multiple comparisons. In The Collected Works of John W. Tukey VIII, 1-300. New York: Chapman and Hall.

Wang, Z., Z. Qi, L. Xue, M. Bukovsky, and M.J. Helmers. 2015. Modeling the impacts of climate change on nitrogen losses and crop yield in a subsurface drained field. Climatic Change 129(1-2):323-335.

Weigel, A.P., R. Knutti, M.A. Liniger, and C. Appenzeller. 2010. Risks of model weighting in multimodel climate projections. Journal of Climate 23(15):4175-4191.

Wesström, I., and I. Messing. 2007. Effects of controlled drainage on $\mathrm{N}$ and $\mathrm{P}$ losses and $\mathrm{N}$ dynamics in a loamy sand with spring crops.Agricultural Water Management 87(3):229-240.

Williams, M.R., K.W. King, and N.R. Fausey. 2015. Drainage water management effects on tile discharge and water quality. Agricultural Water Management 148:43-51.

Workman, S.R., and N.R. Fausey. 1985. Macro relief surface storage on naturally occurring and surface drained plots. Transactions of the American Society of Agricultural Engineers 28(5):1612-1616.

Youssef, M.A., R.W. Skaggs, G.M. Chescheir, and J.W. Gilliam. 2006. Field evaluation of a model for predicting nitrogen losses from drained lands. Journal of Environmental Quality 35(6):2026-2042. 